NBER WORKING PAPER SERIES

\title{
IS MAKING DIVORCE EASIER BAD FOR CHILDREN? THE LONG RUN IMPLICATIONS OF UNILATERAL DIVORCE
}

\author{
Jonathan Gruber
}

Working Paper 7968

http://www.nber.org/papers/w7968

\section{NATIONAL BUREAU OF ECONOMIC RESEARCH 1050 Massachusetts Avenue \\ Cambridge, MA 02138}

October 2000

\begin{abstract}
I am grateful to Amber Batata, Jeffrey Hoffner, Becky Neuschatz, Kokkeong Puah, and Ebonya Washington for excellent research assistance, to John Johnson, Chris Mazingo, Justin Wolfers, and seminar participants at MIT and the NBER for helpful comments, and to the Smith Richardson Foundation for financial support. The views expressed in this paper are those of the author and not necessarily those of the National Bureau of Economic Research.
\end{abstract}

(C) 2000 by Jonathan Gruber. All rights reserved. Short sections of text, not to exceed two paragraphs, may be quoted without explicit permission provided that full credit, including $\mathbb{C}$ notice, is given to the source. 
Is Making Divorce Easier Bad for Children?

The Long Run Implications Of Unilateral Divorce

Jonathan Gruber

NBER Working Paper No. 7968

October 2000

JEL No. J12, J13, J24

\begin{abstract}
Most states in the U.S. allow for unilateral divorce, which increases the ease of divorce by not requiring the explicit consent of both partners. Such regulations have come under fire for their perceived negative consequences for marital stability and resulting child outcomes, but there is no evidence to date to support the contention that easier divorce regulations are actually bad for children. I assess the long run implications for children of growing up in a unilateral divorce environment, by measuring how such youth exposure affects adult outcomes. Using 40 years of census data to exploit the variation across states and over time in changes in divorce regulation, I confirm that unilateral divorce regulations do significantly increase the incidence of divorce. I also find that adults who were exposed to unilateral divorce regulations as children are less well educated and have lower family incomes. They are also more likely themselves to be both married and separated, and both of these effects appear to reflect primarily a shift towards earlier marriage and separation. Women in these exposed cohorts are less attached to the labor force, while men are somewhat more attached; the timing of these effects appears consistent with a causal role for marriage. Thus, exposure to easier divorce regulation as a youth appears to worsen adult outcomes along a number of dimensions, but the ultimate implications depend on the long run impacts of earlier family formation among this cohort.
\end{abstract}

Jonathan Gruber

Department of Economics

MIT

E52-355

50 Memorial Drive

Cambridge, MA 02142

and NBER

gruberj@mit.edu 
One of the most striking trends in postwar social indicators in the U.S. is the rise in divorce rates. Figure 1, updated from Friedberg (1988), illustrates the rate of divorce per 1000 persons in the U.S. over time. After staying at low levels for many years, divorce rates began to rise precipitously in the mid-1960s, with the rate of divorce rising by over $200 \%$ in only fifteen years. This "breakdown of the traditional family" has been decried in many circles, particularly due to its perceived negative implications for children. Indeed, there are large literatures in sociology, developmental psychology, and economics which document the negative consequences for children of divorce, both as children, and then later as adults.

A common villain in these criticisms is state regulations that increase the ease of divorce. The rise in divorce rates corresponds quite strikingly to the advent of state regulations that allowed for unilateral divorce, or divorce that did not require the explicit consent of both partners. Unilateral divorce laws were passed in a number of states in the wake of the no-fault divorce revolution that moved the basis for divorce from the fault of one spouse to general "irreconcilable differences" (Weitzman, 1985). These unilateral laws substantially increased the ease of divorce by allowing one partner to leave without obtaining the consent of the other. The second line in Figure 1 shows the percent of persons living in states with unilateral divorce laws in place. Exposure to these unilateral divorce regimes rose in tandem with divorce rates over the 1970s.

As a result, critics of rising divorce rates have called for a reversal of the 1970s trend towards unilateral divorce regimes, in an effort to maintain the traditional two-parent family and improve child outcomes. Two states (Arizona and Louisiana) have passed "covenant marriage" laws whereby the couple receives pre-marital counseling and signs a covenant that makes divorce 
more costly through separation periods with intensive counseling (although still possible unilaterally). These laws have been proposed in at least 17 other states as well. And there is a broader movement in religious communities as well to increase the stringency of the marriage contract (Nordinger, 1998). In a recent debate over such regulations in Virginia, the Associated Press Wire on February 14, 2000 quoted the legislation's author, Rep. McDonnell, as saying that "he was concerned about the rising divorce rate and the impact it was having on families".

The key underlying assumption of this movement is that regulations which increase the ease of divorce have negative implications for children. This line of argument involves three key suppositions, however: that the increase ease of divorce under state regulations contributed to (or even fully caused) the rising rate of divorce in the U.S.; that divorce is actually bad for children, relative to the counterfactual of maintaining potentially damaged marriages; and that changes in divorce regulation do not have any other impacts on families which may offset any direct influences through divorce, such as through the decision to enter into marriage or through changes in the nature of within-family bargaining. The existing evidence on the first of these suppositions is quite mixed; the evidence on the second has yet to convincingly address potential selection biases associated with the decision to divorce; and there is little empirical work on the third supposition. Thus, on net, there is no convincing evidence that unilateral divorce regulations actually have an adverse impact on child well-being.

The purpose of this paper is to provide a careful assessment of the implications for children of making divorce easier, in a framework which allows me to integrate all of the issues above. I do so in three steps. I first show that there is a sizeable and significant impact of unilateral divorce on the stock of divorced parents of child-bearing age. I then directly examine 
the implications of growing up in a unilateral divorce regime for children when they themselves become adults, allowing for a long run assessment of the ultimate consequences for children of growing up in an environment which divorce is easier. Finally, I extend the basic results to consider the process through which unilateral divorce affects outcomes, by examining how the effects vary with length of exposure to unilateral divorce laws and by age.

I do so by using data on state divorce regulations, matched to information from the 1960 , 1970, 1980, and 1990 censuses. This broad historical sweep allows me to consider both the direct impact of unilateral divorce regimes on the cohorts of adults at the time they are passed, and the later impact on their children when they themselves become adults. And I can do so within models that account for both fixed state preferences towards divorce, as well as changes in those preferences over time.

I have several notable results, besides the finding noted above that unilateral divorce increases the stock of divorces. I find that adults who were exposed to unilateral divorce regulations as children are less well educated and have lower family incomes. They are also more likely themselves to be both married and separated, and both of these effects appear to reflect primarily a shift towards earlier marriage and separation. Women in these exposed cohorts are less attached to the labor force, while men are somewhat more attached; the timing of these effects appears consistent with a causal role for marriage. Thus, exposure to easier divorce regulation as a youth appears to worsen adult outcomes along a number of dimensions, but the ultimate implications depend on the long run impacts of earlier family formation among this cohort.

The paper proceeds as follows. In Part I, I present background on the potential links 
between unilateral divorce laws and child outcomes. In Part II, I discuss my data and empirical strategy. Part III presents the results on the how unilateral divorce impacts marital status. Part IV then examines the impact of exposure to unilateral divorce as a youth (and currently) on adult outcomes. Part V considers a number of extensions of the basic results. Part VI concludes.

\section{Part I: Background}

As noted in the introduction, there are three key links between legislation which makes divorce easier, and the outcomes of children. In this background section, I review each link in turn. Before doing so, I provide some background on the unilateral divorce regulations which are the subject of this study.

\section{Legislative Background}

As nicely reviewed by Weitzman (1985), traditional state regulation in the U.S. provided for divorce only for grounds such as infidelity, physical abuse, etc. Moreover, such divorce had to be mutually agreed upon by both partners. This law was widely viewed as inadequate, largely because of the enormous financial and emotional transaction costs that the establishment of fault placed on the divorce process. Indeed, marriages that were viewed by both parties as "broken" for mundane reasons could not be dissolved without more elaborate justification. And fault was viewed as a tool that was often used by one spouse (typically the wife) to "extort" excessive settlements from the other spouse. As Wheeler (1974, quoted in Weitzman, 1985) wrote:

It was unanimously agreed that elimination of the present grounds... would conform the law to prevailing reality, eliminate the existing evils of dissimulation, hypocrisy, and outright perjury, and end the use of conduct not formally alleged as 
a weapon in obtaining extortionate and frequently inequitable and unworkable concessions from the defending spouse.

These concerns led to a movement for reform of U.S. divorce laws. But, according to Weitzman, the reformers did not appear to recognize that they might be swinging the pendulum too far in the other direction, by removing the powerful property rights that mutual consent, fault divorce gave to women. Indeed, most expert accounts of this period viewed this reform as an attempt to remove the legal inefficiencies of the divorce process, not as a tool of social policy.

The first steps in these reforms was moving to no-fault divorce, which was in place before 1950 in a number states, while maintaining the mutual consent feature. Unilateral divorce, which allowed divorce with the consent of just one rather than both spouses, was rare before the late 1960s but was in place in most states by the mid-1970s. My paper focuses on unilateral divorce, following the economics literature growing out of Peters (1986), which is discussed in more detail below.

I have documented the availability of unilateral divorce in each state from 1950 to the present, updating the legislative details in Friedberg (1998). The results of doing so are presented in Table 1. ${ }^{1}$ States could pass either unrestricted unilateral divorce, or unilateral divorce with the requirement that spouses live separated for some period of time (typically 1-5 years). I focus on unilateral divorce laws that do not include separation requirements; Friedberg finds that the impacts of laws with separation requirements on divorce flows is positive, but

\footnotetext{
${ }^{1}$ There is some disagreement in both the economics and legal literatures on the appropriate coding of unilateral divorce. This table is based on a careful state-by-state review of the actual divorce laws to ensure a consistent definition. An appendix is available on request which gives the legislative cites and language for each states's law, and which compares this definition to that used by other authors. There are ambiguities in coding for two small states (Delaware, and Montana), but the results are not sensitive to alternative coding of these states.
} 
much weaker than for unrestricted unilateral divorce.

\section{Does Unilateral Divorce Affect Divorce Decisions?}

As noted above, unilateral (and no fault) divorce is perceived to be a cause of the dramatic rise in divorce rates in the U.S. Besides the obvious time series parallels, the theory behind such arguments is perceived to be quite straightforward: if there is one partner that wants to terminate the marriage, but the other does not, then a unilateral divorce will cause the marriage to end.

In a well-known article, Peters (1986) pointed out the flaw in this theory from the perspective of Coasian bargaining. If a marriage is a contract between two partners, and one partner wants to end that contract, he or she can just pay their partner for that privilege. Thus, moving from multilateral to unilateral divorce does not change the fundamental likelihood of divorce; it simply changes the amount of payment that must be made from the partner who wants to leave to the partner who wants to stay. That is, under the typical presumption from the $1970 \mathrm{~s}$ that men were the ones that wanted to terminate their marriage contracts, unilateral divorce would not lead to rising divorce; it would simply lead to lower alimony and child support payments to the wives left behind.

Peters supported her theoretical argument with an empirical analysis of the impact of unilateral divorce regimes on divorce rates. She used a cross-section of data on women to examine whether women were more likely to be divorced in states with unilateral divorce regimes, and she found no significant correspondence between the two.

This striking conclusion generated a number of follow-on analyses, with mixed results. 
Allen (1992) claimed that for alternative specifications of the divorce variable and the model there were impacts of unilateral divorce regimes on divorce, but Peters (1992) disputed his law classification and his omission of important regional controls. Friedberg (1998) carefully revisited this question using panel data on divorce rates by state and year, and found that for the most detailed specification there was an impact of unilateral divorce on divorce rates; similar analysis is found in Reilly and Evenhouse (1997). Wolfers (2000) shows that much of Friedberg's effect on flows of divorces arose from a large increase in divorces soon after the passage of unilateral divorce laws, and that the long run effect on the divorce flow is quite small. But Gray (1998) does not find an impact of unilateral divorce on divorce rates using the 1970 and 1980 censuses. Thus, the impact of unilateral divorce regimes on divorce rates remains an open question.

\section{Is Divorce Bad For Children?}

The second supposition that drives criticisms of easier divorce regulations is that divorce is actually bad for children. This supposition is supported by an enormous literature which can only be crudely summarized here. After reviewing 92 studies, Amato and Keith (1991) report that children of divorce have more difficulty than children in intact families adjusting both socially and psychologically. Surveys show that children of divorce are more likely to exhibit behavior that is antisocial, impulsive or acting out. They are more likely to become delinquents (Matsueda and Heimer 1987, Zill et al 1993), and perform worse academically; Guidubali, Perry and Cleminshaw (1984) find that first, third and fifth graders from divorced families (compared with children of intact families) scored lowered on IQ, reading, spelling and math scores. They 
are also more likely to suffer psychological symptoms such as dependency, low self-esteem, anxiety and depression. Children whose parents have divorced score above clinical cutoffs on psychological tests of behavior problems twice as often ( $20 \%$ vs. $10 \%)$ in comparison to children from intact households. (See for example Achenberg and Edelbrock, 1983, Hetherington and Clingempeel, 1989, Isaacs, 1986).

The research on adolescents from divorced families also documents negative consequences. Adolescents of divorce are two to three times more likely to drop out of school, become pregnant, engage in antisocial and delinquent behavior, and score above clinical cutoffs on standardized tests of behavior (Acenback and Edelbroch, 1983). They begin to date and have sex at younger age (Flewelling and Bauman, 1990). Other researchers find that these youngsters are more aggressive, noncompliant, sexually active and likely to use and abuse drugs and alcohol than adolescents from intact households (Baumrin, 1989; Doherty and Needle, 1991, Dornbusch et. al, 1985). Adolescents of divorce are more likely to have lower academic performance and higher dropout rates even after controlling for socio-economic status (Guidubaldi et. al., 1984; Krein and Beller, 1988).

By age 23, a British longitudinal study of children shows, children of divorce are more likely to leave home because of friction (Cherlin et. al. 1995). Adult children of divorce are less likely to attend or complete college, more likely to be unemployed and on welfare and to possess fewer resources (Keith and Finley, 1988; McLeod, 1991; McLananahan and Sandefur, 1994; Aquilino, 1994; Cooney, 1994). Children of divorce marry and cohabit at earlier ages, and are more likely to terminate those marriages through separation or divorce (McLanahan and Bumpass, 1988; Amato and Keith, 1991; Kiernan and Hobcraft, 1997; Feng et al., 1999; Kiernan 
and Cherlin, 1999), although Wolfinger (1999) claims that transmission of divorce across generations is waning.

Thus, the negative implications of divorce for children are broadly supported by a large previous literature (and the even larger volume of research not summarized above). But a central limitation of these studies is that divorce is not an exogenous event with respect to other determinants of child outcomes. Another large literature on the determinants of divorce finds that divorce is strongly correlated with socioeconomic characteristics that also determine child outcomes, such as income and family size. For example, divorce rates are higher when men have experienced serious unemployment within the past five years (Ross and Sawhill, 1975), and states with higher male earnings have lower divorce rates (Ferber and Sander, 1989). Moreover, in theory, the implications of divorce for child well being are ambiguous. While depriving the family of one potential earner and caregiver can clearly have negative implications, breaking up emotionally or physically harmful marriages can have benefits for children.

A number of the studies above attempt to control for socioeconomic characteristics in assessing the impact of divorce (e.g. McLanahan and Sandefur, 1994). But they do so armed with only a limited set of family background characteristics that might not fully capture underlying differences between families and do and do not divorce. Even conditional on background characteristics such as socioeconomic status, families that choose to divorce are different in unmeasured ways, and these differences can have important implications for children; for example, it may be the families with the weakest tastes for marriage that divorce, and this could lead to more unstable marriages among their children not because of parental divorce per se, but rather because of inherited weak tastes for marriage. 
What is required to appropriately identify the impacts of divorce is an exogenous instrument that causes some families to divorce and others not, based on a factor independent of the determinants of their children's outcomes. No previous study has been able to uncover such an instrument, making it somewhat hard to interpret causally this large literature.

Moreover, the previous literature has focused on the impact of the average divorce, not of the marginal divorce that is induced by a change in the regulatory regime. Even relative to the effects of divorce on average, the divorces induced by a shift to unilateral divorce regulation may have larger or smaller negative implications for children. For example, the average divorce may be taking place for reasons of fault, such as spousal abuse or infidelity, while the marginal divorce that arises from a law change is due to spousal incompatibility. If marriages that end due to abuse or infidelity have worse/better implications for children than do marriages that end due to incompatibility, then unilateral law-induced divorces will have better/worse implications than the average divorce.

Are There Other (Potentially Offsetting) Impacts of Unilateral Divorce?

The third supposition behind these arguments is that there are not offsetting impacts of unilateral divorce on child well being. In fact, there are at least three additional effects that unilateral divorce regulations may have on child well being, beyond direct effects on the propensity to divorce; these effects may either offset, or augment, the direct divorce effects. First, and most obviously, unilateral divorce can lower the incidence of separation, as families substitute official for de facto divorce; that is, parents who are living apart may now formalize a divorce. If it is having two parents in residence that is important for child development, then 
such a shift may be of little consequence for well-being.

Moreover, unilateral divorce may increase the incidence of marriage, by reducing the barriers to exiting that marriage. That is, individuals who are reticent to enter marriage in a regime where unilaterally terminating that marriage is not possible may be more willing when they have a source of exit. Unilateral divorce may thereby lead to more "marital churning", with both more marriages and more divorces, and little impact on the net stock of married couples (or of children living in two-parent households). If what matters for child well-being is being in a two-parent household, then even if divorce is rising in unilateral divorce regimes, child outcomes may be unaffected. This point has not been considered by previous empirical studies, which have focused on divorce, and not marriage, as the outcome of interest; but it is discussed theoretically in Bougheas and Georgellis (1999).

Finally, even if families see no change in marital status as a result of unilateral divorce, making divorce easier can change the nature of the bargaining relationships between husband and wife. If these relative positions of power have implications for child well-being, then this is an additional channel through which unilateral divorce can impact children. For example, there is a large literature which suggests that resources in the hands of women are more beneficial to children than are resources in the hands of men (e.g. Strauss \& Thomas, 1995). If unilateral divorce weakens the within-household bargaining position of the wife, because the husband can now leave without large compensation, this may have negative implications for children, who benefitted from the relative power of their mothers. Of course, this effect could operate in the opposite manner as well, depending on who is strengthened and who weakened by this change in property rights. 
This paper will not be able to separate the direct effects of unilateral divorce through divorce versus the indirect effects through these other channels. But the existence of these other channels highlights that unilateral divorce laws are not useful instruments for divorce. That is, moving to a unilateral divorce regime has impacts that go beyond any simple effect on the divorce rate. Thus, the results from this exercise should be interpreted as the reduced form effects of making divorce easier on outcomes, and not as the structural effects of divorce on outcomes.

A new paper by Johnson and Mazingo (2000), written at the same time as this paper, also explores the implications of unilateral divorce for child outcomes as adults. They follow a somewhat different strategy than the one employed here, using cross-sectional data from the 1990 census to compare the effects of unilateral divorce on those exposed to the law for different lengths of time as a child. A number of their key findings echo those reported below, although, as I describe below, it is impossible to separate the impact of the amount of time exposed to these laws from the age first exposed, suggesting that it is useful to begin by examining whether a child was exposed at all.

\section{Part II: Data}

The data for this analysis comes from the 1960, 1970, 1980, and 1990 PUMS files from the U.S. census. These data provide very large samples so that information can readily be gleaned on the response to state divorce laws. Most importantly, the data also report both state of current residence and state of birth, and they cover the period both during the unilateral reforms and many years thereafter, so that the effect of both current and youth exposure to unilateral 
divorce can be assessed. Due to the large samples, and the fact that the relevant legislative variables vary only at the state/year/age level, the data are collapsed into state/year/age cells for the analysis.

These data are parsed into three data files for the analysis. The first has information by state of residence and year for children 0-18 years old, so that data are cells by state, year, and child's age; all regressions are weighted by cell size to replicate the underlying microdata. This file contains information on the marital status of the parent with whom the child resides. The second data set is the parallel data set by state/year/age for adults of child-rearing age (25-50 years old), to examine the impact of unilateral divorce laws in one's state of residence on own divorce probabilities.

The third file is a data set for adults age $25-50$ that is organized by age, state of birth, state of residence, and sex. This finer level of detail is necessary for us to examine jointly the impact of unilateral divorce regimes with which the individual grew up and unilateral divorce regimes within which they now reside. The data are also divided by sex because many of the outcomes I examine (e.g. labor force participation) differ significantly across the sexes. These data have information for each of these cells on marital status, family size, family income, individual education, individual work status, and individual earnings. Once again, these are all averages for the year/age/state of birth/state of residence/sex cell, and the regression is run at that level, weighted by cell size.

These census data are matched to information on the presence of unilateral divorce regimes across states and over time. The means of the first and third data sets are presented in Table 2; the means in the second and third data sets for adults are identical, since the third is just 
a more finely parsed version of the second. Among children, $6.6 \%$ are living with a divorced mother, and roughly $1 \%$ are living with a divorced father. Among all adults of child bearing age, $11 \%$ of females and $8.2 \%$ of males are divorced.

\section{Part III: Does Unilateral Divorce Affect Marital Status?}

In this section, I address the first of the predicate questions raised above: does unilateral divorce actually affect marital status? I examine both the impact on the likelihood that adults are divorced, and the impact on other marital states that may be affected by this shift in legal regimes. As noted earlier, while a number of papers have focused on the impact of unilateral divorce on the flow of divorces, only Gray (1998) has looked at the stock, and he finds little impact.

To assess the impact of unilateral divorce on marital status, I run regressions of the form:

$$
\text { DIVORCE }_{\mathrm{ajt}}=\alpha+\beta_{1} \mathrm{UNILAT}_{\mathrm{jt}-1}+\beta_{2} \mathrm{RACE}_{\mathrm{ajt}}+\beta_{3} \eta_{\mathrm{a}}+\beta_{4} \delta_{\mathrm{j}}+\beta_{5} \tau_{\mathrm{t}}+\beta_{6} \eta_{\mathrm{a}} * \tau_{\mathrm{t}}+\epsilon
$$

where a indexes ages, $\mathrm{j}$ indexes states, and $\mathrm{t}$ indexes years; DIVORCE is the cell mean divorce rate (or some other marital status indicator); UNILAT is a dummy for the presence of a unilateral reform law in the year before the census year (since the census is carried out in the spring of the year and many of the questions that I will use refer to the previous year); RACE are

dummies for percent black and white, respectively, in the cell; $\eta_{\mathrm{a}}, \delta_{\mathrm{j}}$, and $\tau_{\mathrm{t}}$ are full sets of dummies for age group, state, and year, respectively; and $\eta_{\mathrm{a}}{ }^{*} \tau_{\mathrm{t}}$ is a full set of age*year interactions to allow for differential time patterns by age. This model controls for fixed factors that vary by age, location, or year, and is identified by the passage of unilateral divorce laws over time. 
One concern with this approach, however, is that there may be trends in marital status that are correlated with the passage of unilateral divorce laws. That is, unilateral divorce may pass where divorce is rising, rather than the opposite causal interpretation. The evidence in Wolfers (2000) suggests that there are not large pre-existing trends in divorce rates in the unilateral divorce states, once data back to 1960 is used. Nevertheless, I will attempt to address this concern by including in the model, along with state fixed effect, state-specific trends. This is not a perfect solution given these census data, since there are only four underlying time series observations, so fixed trend models are fairly demanding. Moreover, if the endogeneity is in the short run, then trends that measure decade time spans (as with the census) will miss them. But this is the best feasible approach to the problem, and if the results are robust to the inclusion of trends it offers some comfort that they are not driven by endogeneity of the laws.

Another econometric concern is that the variable of interest (unilateral divorce laws) varies only by state and year, while the underlying data here also varies by single year of age. As a result, I correct all standard errors for clustering on state of residence and year.

The results of running regressions such as this for various measures of marital status are shown in Table 3. The first set of columns is for women, and the second set for men. Within each set of columns, I show results with and without state-specific trend controls. Within each cell, I present the coefficient, the standard error (in parentheses), and percentage impact (relative to means in Table 2). The coefficients are all multiplied by 100 for ease of interpretability. Each cell in the table is from a separate regression.

I find that there is a very sizeable and highly significant impact of unilateral divorce on the likelihood of being divorced. For women, unilateral divorce being place raises the odds of 
divorce by 0.0127 percentage points, or $11.6 \%$. For men, the increase is 0.0095 percentage points, or $11.6 \%$. The results are even stronger when state-specific trends are included, with the coefficient for females rising to 0.014 percentage points (12.7\%) and for men rising to 0.0096 percentage points $(11.7 \%)$.

On the other hand, there is no robust evidence on the odds of being either separated or never married. For women, there is some suggestion of a reduction in the odds of being never married, but it is highly insignificant and small when state trends are included; for men, the effect is wrong-signed with trends included.

These results show the effects on parents of child-bearing age. But it is possible that the impacts of divorce reform may be different for parents who actually have children. So the next panel of Table 3 focuses on the marital status of parents of children in the data set. The regression run is the same as above, except that the sample is now children age $0-18$, and the dependent variables are whether their mother or father are divorced, separated, or never married.

The results for the parents of children echo those for adults of child-bearing age. Controlling for state-specific trends, there is a 0.0096 percentage point increase in the odds that a child is living with a divorced mother, which is $14.5 \%$ of baseline, and a 0.0011 percentage point increase in the odds of living with a divorced father, which is $11.1 \%$ of baseline. Overall, the odds of living with a divorced parent rise by 0.0107 percentage points, which is quite similar to the odds for adults of being divorced. These child-based results offer more evidence for increased entry into marriage when divorce is made easier. For mothers, in the model without trends, there is a very large impact on the odds of living with a never married mother; however, this result disappears when trends are included. For fathers, the impact is significant even when 
trends are included. There are negligible impacts on living with separated parents. ${ }^{2}$

Thus, there is clear evidence from the census data that making divorce easier increases the stock of divorced women and men, and that as a result children are more likely to be living with a divorced parent. There is mixed evidence for an offsetting impact on other marital decisions.

\section{Part IV: Impact of Unilateral Divorce on Outcomes}

I now turn to assessing the impact of unilateral divorce as a youth on adult outcomes. To do so, I turn to the data which is created by both state of residence and state of birth, and run expanded regressions of the form:

$$
\begin{aligned}
& \text { OUTCOME }_{\text {ajt }}=\alpha+\beta_{1} \text { UNILAT }_{j \mathrm{t}-1}+\beta_{2} \mathrm{KIDUNI}_{\mathrm{abt}}+\beta_{3} \mathrm{RACE}_{\mathrm{ajt}}+\beta_{4} \eta_{\mathrm{a}}+\beta_{5} \sigma_{\mathrm{b}}+\beta_{6} \delta_{\mathrm{j}}+ \\
& \beta_{7} \tau_{t}+\beta_{8} \eta_{a}^{*} \tau_{t}+\epsilon
\end{aligned}
$$

where, in addition to the other indices, $b$ indexes state of birth; OUTCOME is one of the

measures of outcomes; KIDUNI is a dummy for having a unilateral divorce law in your state of

birth before you were age 18 ; and $\sigma_{\mathrm{b}}$ is a full set of state of birth dummies. Thus, this regression framework allows for both effects of contemporaneous and youth laws on outcomes. Once again, I also explore the sensitivity of results to state-specific trends, where now I include trends for both state of birth and state of residence. And the standard errors are now corrected for state

${ }^{2}$ One problem with these data is that they only measure marital status at a point in time. As a result, adults may have been divorced and remarried, and children may have thus been exposed to some time in a divorced family, but it will not be captured here. I can explore this in the 1970 and 1980 censuses, which along with current marital status asked about previous marital status. The basic results for current marital status are similar when restricted to these censuses. There is in fact a negative and insignificant impact on the odds of being married and previously divorced, which actually offsets somewhat the positive impact on being divorced. 
of residence $*$ state of birth * year clustering.

The results of running these regressions for females age 25-50 are presented in Table 4. The first and third columns show the results of estimating equation (2) without trends, and present the key coefficients on KIDUNI and UNILAT; the second and fourth columns show the results of estimating equation (2) with trends, and once again present those same coefficients. So there are two regressions presented per row.

I show the results for several sets of variables, denoted in blocks in the table. Since there are many outcome variables and their effects are likely to be related, I first review below the full set of findings, and then after doing so turn to offering discussion of their implications. For regressions where the dependent variable is a cell mean of a discrete variable (e.g. marital status measures), the coefficients on unilateral variables are multiplied by 100; for continuous variables (e.g. number of children, years of education, earnings), the coefficients are directly reported (and not multiplied by 100).

\section{Results}

The first block of results shows the impact on marital status and number of children; the coefficients for current divorce law parallel those shown in Table 3, and the results are indeed quite similar, suggesting little bias from examining the current laws in a vacuum (ignoring youth laws). But the coefficients for laws as a youth are strikingly different: I find that unilateral divorce as a youth is associated with no rise in the odds of being divorced, but a much higher likelihood of being married. The coefficient with state-specific trends included indicates that being exposed to unilateral divorce as a youth raises the odds of being married by 0.0066 
percentage points, or $0.9 \%$ of the sample mean. There is a correspondingly much lower likelihood of being never married. There is also a significant rise in the odds of being separated. These results are all very robust to the inclusion of state-specific time trends; indeed, the trends serve to increase the precision with which the coefficients are estimated.

Corresponding to the increase in the odds of being married, there is a significant rise in the number of children on average associated with being exposed to unilateral divorce as a youth. This result is somewhat sensitive to the inclusion of trends, with the coefficient doubling to 0.021 more children if exposed to a unilateral divorce regime as a youth.

The next block examines the impact of unilateral divorce on educational attainment. There is in fact a significant decline in years of education attained for those exposed to unilateral divorce as a youth, with exposure associated with 0.065 fewer years of education $(0.6 \%$ of mean). This impact appears to arise mostly from a significant and sizeable increase in the odds of being a high school graduate, and a corresponding large decline in the odds of being a college graduate. There is a also a large increase in the odds of being a high school dropout. There is little net effect on the odds of getting some college education (but not a degree), but this result is hard to interpret since there are both flows into this group (from reductions in college completion) and flows out (from reductions in college attainment).

The next block examines the impact on living standards. There is a significant deterioration in average income per capita for those women exposed to unilateral divorce as a youth, with exposure associated with a reduction in income per capita of $\$ 431$, or $3.2 \%$. But there is no effect on the percentage of the cell living below the poverty line, suggesting that the 
reductions in income are concentrated in middle and higher income families. ${ }^{3}$

The next block shows the impact of unilateral divorce on labor supply. Being exposed to unilateral divorce as a youth significantly lowers labor supply. The odds of being employed fall by 0.48 percent, which is $0.7 \%$ of the sample mean; weeks worked fall by 0.32 , which is $1 \%$ of the sample mean; and earnings fall by $\$ 246$, which is $2.3 \%$ of the sample mean. The much larger impact on earnings than on labor supplied implies that wage rates are falling as well; direct examination of hourly wages yields a negative, but insignificant, coefficient.

Table 5 shows corresponding results for males. The basic pattern of results for the first three blocks is quite similar: increased marriage probabilities; reduced educational attainment; and reduced living standards. But the effects on labor supply are quite different: being exposed to unilateral divorce as a youth appears to increase labor supply for men, albeit not significantly.

The second set of columns in both tables shows the results of current unilateral divorce regimes. In both cases, except for marital status, there are relatively few significant coefficients. This reflects the much more limited variation in the current unilateral regime than in the state of birth unilateral regime.

\section{Interpretation}

This panoply of results paints an interesting picture of the impact of being exposed to unilateral divorce as a youth. Exposure to unilateral divorce leads for both men and women to more marriage (but more separation as well), less education, and lower family incomes. For

${ }^{3}$ While easy to interpret, income per capita measures ignore economies of scale from changes in family size. But the results are very similar if I use instead a measure of the ratio of family income to the poverty line, which uses census equivalence scales to adjust. 
women, being exposed to unilateral divorce leads to lower labor force attachment and earnings; for men, labor force attachment and earnings actually rise, albeit insignificantly.

Distinguishing causal pathways for these effects, however, is somewhat difficult, as educational attainment, marital status, and labor force attachment are all jointly determined. Since, in the raw data, there is a strong positive association between education and marriage, it seems likely that the increase in marriage and reduction in education are both direct effects of unilateral divorce, rather than one being a secondary effect of the other. The increase in marriage is not inconsistent with the previous literature, which found earlier marital formation for children of divorce; in these cross-sections of a given set of ages, a higher likelihood of being married on average could result from either increased odds of marriage at every age or from a shift forward in the timing of marriage. I return to this point below.

The reduction in education could arise from at least two channels. The first is liquidity constraints: to the extent that children of divorce have fewer resources, they may be unable to afford higher education. The second is stress in childhood which leads to worse performance in school as a youth, with resulting ramifications for ultimate educational attainment. The fact that, for women at least, the impact on high school graduation is much larger than on dropping out from high school would be consistent with liquidity constraints operating particularly on the college attendance margin; this is not true for men, however, where there are equal effects on high school dropping out and on high school graduation. ${ }^{4}$

\footnotetext{
${ }^{4} \mathrm{~A}$ liquidity constraints explanation for reduced educational attainment would suggest that the effect would be largest where the costs of secondary education are the highest. To assess whether this is true, I obtained data on public school tuition levels across the states and estimated models where I allowed the education effects to vary by underlying public tuition levels (I am grateful to David Card for providing these data). The data are far from ideal for my purposes;
} 
The reduction in labor force attachment and earnings for women could arise directly through unilateral divorce impacts, or indirectly through either of the marriage or education channels. The direction of the impacts is inconsistent with a causal pathway through education, as both males and females are suffering similar reductions in educational attainment, but female labor supply falls while male labor supply rises. On the other hand, the direction is consistent with the reduction in female labor supply and increase in male labor supply that would typically arise from marriage. But even here the magnitudes are too large to be explained by typical estimates of the effect of marriage on labor supply. For example, cross-sectional estimates in our census data show that being married lowers earnings by $70 \%$ for females; at this magnitude, a $0.66 \%$ rise in the odds of marriage cannot explain a $2.3 \%$ decline in earnings. On the other hand, these cross-sectional estimates suffer from a number of selection biases which make it hard to use them to infer the indirect effect of unilateral divorce through marriage on labor supply. Further evidence presented below is consistent with a causal pattern from marriage decisions to labor supply.

Another interpretive issue with these results is the mechanisms through which unilateral divorce regulation leads to later outcomes: is it solely through increased divorce, or through the other mechanisms discussed above? It is impossible to answer this question precisely, given that I only have one instrument and two channels of effects. But back of the envelope calculations

they only go back to 1972, whereas most of my sample graduated high school well before then. I therefore made a ranking of the states in terms of their tuition levels, and used the average ranking over the 1972-1983 period as my regressor for all cohorts, assuming that states are either consistently high or low tuition state. Doing so, I found no evidence of stronger reductions in college attainment from unilateral divorce where tuition ranking was higher. But this test is not a strong one due to the limitations of the tuition data for my purposes. 
from the estimates in Tables 3 and 4 suggest that the effects of divorce must be enormous if unilateral divorce has its impacts through the divorce channel only. For example, I find in Table 3 that the odds for a child of living with a divorced parent is rising by 0.0107 percentage points. Putting this together with the findings in Table 4, and assuming that the impacts of unilateral divorce arise through increased divorce only, would imply that coming from a divorced family raises for females the odds of being married by 62 percentage points $(84 \%)$, lowers education by 6.1 years $(56 \%)$, lowers the odds of graduating college by 140 percentage points $(607 \%)$, lowers average incomes per capita by $\$ 40,340$ (300\%), and lowers earnings by $\$ 23,016(215 \%)$ ! These substantial effects seem unlikely to be driven solely by parental divorce. ${ }^{5}$

\section{Part V: Extensions}

The initial results are suggestive of important long run effects of unilateral divorce on adult outcomes. In this section, I consider a two extensions designed to assess the mechanisms through which these effects arise.

\section{Exposure to Laws}

One interesting question is whether the amount of exposure to unilateral divorce laws strengthens the effects that have been shown thus far. To the extent that additional years of exposure to unilateral divorce regimes raises the odds that parents divorce, it could lead to

${ }^{5}$ Of course, to the extent that some children exposed to divorce are now in remarried households, this "first stage" coefficient will understate the net effect of divorce exposure, so that these implied IV coefficients are too large. But, as noted earlier, data from 1970 and 1980 do not suggest a rise in the odds of living with a remarried mother when exposed to unilateral divorce, so this does not seem an empirically important consideration. 
stronger impacts on the outcome of children who grow up in unilateral divorce regimes. On the other hand, if there is a pent-up stock of divorce demand that is satisfied shortly after the unilateral divorce law is passed, and then divorces decline again, there may not be a strong relationship with exposure. Wolfers (2000) suggests that such a "blip" may occur over the first eight years that a unilateral divorce law is in place.

Examining impacts by amount of exposure also has the potential to help determine the causal pathways of the effects that were shown above, in two senses. First, if the time pattern of impacts of later outcomes matches that of exposure to divorce, then it lends some credence to the notion that the effects are occurring through the divorce channel and not other (e.g. household bargaining) channels. Second, if the time pattern of some effects (e.g. marriage) matches that of others (e.g. labor supply), it provides some more evidence that can be helpful in interpreting causal pathways of effects of unilateral divorce.

To examine exposure effects, I calculate the number of years that each adult in the sample was exposed to unilateral divorce as an adult (after age 18) and as a youth (up through age 18). I then divide these current unilateral and unilateral as youth dummies into three exposure categories: one to four years of exposure; five to eight years of exposure; and nine or more years of exposure. It is important to note that, by the nature of the construction of years exposed, the exposure effects of laws as a youth pick up two effects: amount of time exposed and age first exposed. That is, an individual who is exposed for 8 years is by definition first exposed at age 10. This makes it difficult to interpret the effects below as effects of additional exposure rather 
than as affects of being exposed at a younger age. ${ }^{6}$

Table 6 first explores the impact of additional exposure on marital status, mirroring Table 3. For presentational simplicity, I show only the results with state-specific trends. The basic finding from both female divorce, and for the odds of living with a divorce mother, is that there appears to be an increasing effect from 1-4 to 5-8 years of exposure, but little additional effect beyond eight years. This is consistent with Wolfers' (2000) conclusion. For men and for the odds of living with a divorced father, there is more of a monotonic increase over all three ranges.

I also find an interesting pattern of exposure effects for the variables measuring unilateral exposure as a youth, as shown in Table 7; the first set of columns show results for females, and the second set for males, and all results include state-specific trends. For the marital status and labor supply variables, the impacts are roughly constant or only slightly increasing for 1-4 and 58 years of exposure, and then growing substantially after eight years. The pattern of effects on years of education is fairly flat; but when subcategories of education are examined, there emerges the same pattern of relatively flat effects through eight years and then a significant rise for nine or more years of exposure. Thus, this exposure timing evidence appears to confirm that channels other than increased divorce are responsible for the impacts of unilateral divorce that we observe. Despite an impact of unilateral divorce on divorce levels that is fairly flat after eight years, the impacts on marriage and labor supply increase significantly with eight or more years of exposure.

In terms of causal channels among the impacts of unilateral divorce, these findings appear to offer further suggestion of a causal effect of marriage patterns on labor supply. Reductions in

${ }^{6}$ The framework used in this subsection mirrors that used by Johnson and Mazingo (2000) in their recent working paper. The results are broadly consistent with their findings. 
earnings for women, and increases for men, are occurring mostly after eight years of exposure, which is exactly when the marriage effect grows.

Age Effects on Marriage

As shown above, exposure to unilateral divorce as a youth leads to a higher likelihood of being married. But, in these cross-sections of a given set of ages, a higher likelihood of being married on average could result from either increased odds of marriage at every age or from a shift forward in the timing of marriage. I explore this issue in Table 8. I show the results, for the marriage variables, of models that interact the current unilateral law and unilateral as youth dummies with age. I focus solely on results with state-specific trends. The first block of the table shows the results for women; the second block for men.

In fact, I find that the effects of exposure to unilateral divorce as a youth on marriage appear to mostly arise through marriage timing. The age interaction with the unilateral-as-youth dummy is negative, significant, and sizeable; it indicates that the impact at age 25 is .015 percentage points, but that by age 36 the impact is roughly zero. That is, unilateral divorce exposure as a youth raises the odds of being married at younger ages, but actually lowers them at older ages. Moreover, there are positive and large impacts on being divorced (not significant) and separated (significant) at younger ages that also fade with time. The pattern of results is very similar for males. It is also interesting to note that, for current exposure to unilateral divorce regimes, there are only very modest increases in the impact of unilateral divorce on divorce propensities with age for women, although more sizeable increases with age for men.

Thus, the findings here echo the conclusions of the observational literature on 
intergenerational effects of divorce cited earlier: exposure to easier divorce as a child leads to earlier marriage, but more marital instability as well. By the time adults are in their late 30s, in fact, there is little net impact on marital status. This suggests that these children of easier divorce laws, perhaps reacting to increased parental marital instability induced by easier divorce laws, move more quickly to form their own unions once they leave the home, but that these unions end up being less stable than do marriages of children not exposed to unilateral divorce.

Moreover, in results not reported, I have investigated the age interaction effects on labor supply, and they continue to be consistent with a causal pathway through marriage: both the reduction in labor supply for women and the increase in labor supply for men fade with age. Thus, while the magnitudes of the labor supply effects appear too large to be explained by marriage impacts, the pattern of results continues to suggest that causal pathway.

\section{Part VI: Conclusions}

Does making divorce easier have negative long run implications for children? The results in this paper suggest that the answer is a qualified yes. Those who are exposed to unilateral divorce regulations are more likely to be living with divorced parents as youths. As adults, they are less educated and have lower family incomes. These lower family incomes appear to largely arise because of earlier marriage, more children, and reduced labor force attachment by women. The evidence on both amount of exposure to the laws and on timing of the law impacts suggests that the reduction in female labor supply arises through this increase in marriage propensities. But these earlier marriages also appear to be more likely to end in separation and divorce; on net there is little impact on marital status at middle ages, but more marital churning at younger ages. 
Thus, the qualification: children of unilateral divorce are living with worse living standards later in life, but largely because the females in this group are staying at home with children rather than working at younger ages. Therefore, the question of whether making divorce easier is bad for children is fundamentally determined by the welfare impacts of this earlier family formation and resulting reduction in labor supply. In other words, the answer to this question gets pushed back yet another generation: is it beneficial or detrimental for the "grandchildren" of unilateral divorce to be born to younger mothers, with lower incomes but more maternal time in the home? Given that the children of unilateral divorce regulations are not only marrying but also dissolving marriages earlier and more frequently, it seems likely that this was on net detrimental to this "grandchild" cohort. But further research is required to confirm this conclusion.

Moreover, further research is necessary to understand the mechanisms behind the results uncovered here. For example, the impacts on adult outcomes appear simply too large to be explained by increased exposure to divorce as a youth; clearly, these laws had other effects which impacted the upbringing of youths. Trying to get inside the "black box" of intact marriages, particularly with respect to issues of bargaining power, is central to assessing these causal pathways. 


\section{References}

Achenbach, T. and C. S. Edelbrock (1983). "A Manual for the Child Behavior Checklist and Revised Child Behavior Profile,” New York: Queen City Printers.

Allen, Douglas (1992). “Marriage and Divorce: A Comment on Peters," American Economic Review, 82, 677-685.

Amato, P. R. and B. Keith (1991). "Parental Divorce and the Well-Being of Children: A Meta Analysis," Psychological Bulletin, 110, 26-46.

Aquilino, W. S.(1994). "Impact of Childhood Family Disruption on Young Adults' Relationships with Parents," Journal of Marriage and the Family, 56, 295-313.

Baumrind, D. (1989). "Sex-Differentiated Socialization Effects in Childhood and Adolescence in Divorced and Intact Families," Paper presented at the biennial meetings of the Society for Research on Child Development, Kansas City, MO.

Bougheas, Spiros, and Yannis Georgellis (1999). "The Effect of Divorce Costs on Marriage Formation and Dissolution," Journal of Population Economics, 12, 489-498.

Cherlin, Andrew J., Kathleen E. Kiernan and P. Lindsay Chase-Lansdale (1995). "Parental Divorce in Childhood and Demographic Outcomes in Young Children," Demography, 32, Issue 3. 299-315.

Cooney, T. M.(1994). "Young Adults' Relations with Parents: The Influence of Recent parental Divorce," Journal of Marriage and the Family, 56, 45-56.

Doherty, W. J. and R. H. Needle (1991). "Psychological Adjustment and Substance Abuse Among Adolescents Before and After a Parental Divorce," Child Development, 62, 328337.

Dormbush, S., J. Carlsmith, S. Bushwall, P. Ritter, H. Leiderman, A. Hastor and R. Gross (1985). "Single Parents Extended Households and the Control of Adolescents," Child Development, 56, 326-341.

Feng, Du, Roseanne Giarruso, Vern Bentson and Nancy Frye (1999). "Intergenerational Transmission of Marital Quality and Marital Instability," Journal of Marriage and the Family, 61, 451-463.

Ferber, Marianne, and William Sander (1989). "Of Women, Men, and Divorce: Not by Economics Alone," Review of Social Economy, 47, 15-26. 
Flewelling, R. L. and K. E. Bauman (1990). "Family Structure as Predictor of Initial Substance Use and Sexual Intercourse in Early Adolesence," Journal of Marriage and the Family, $52,171-181$.

Friedberg, Leora (1998). "Did Unilateral Divorce Raise Divorce Rates? Evidence from Panel Data," American Economic Review, 88, 608-627.

Gray, Jeffrey (1998). "Divorce Law Changes, Household Bargaining, and married Women's Labor Supply," American Economic Review, 88, 628-42.

Guidubaldi, J., J. D. Perry and H. K. Cleminshaw (1984). "The Legacy of Parental Divorce: A Nationwide Study of Family Status and Selected Mediating Variables on Children's Academic and Social Competencies," In B. B. Lahey and A. E. Kazdin (Eds.) Advances in Clinical Child Psychology, 7, New York: Plemum Press. 109-151.

Hetherington, E. M. "Social Capital and Development of Youth from Nondivorced, Divorced and Remarried Families," In A. Collins (Ed.) Relationships as Developmental Contexts: The $29^{\text {th }}$ Minnesota Symposium on Child Psychology. Hillsdale, NJ: Lawrence Erlbaum.

Hetherington, E. M. and W. G. Clingempeel (1989). "Coping with Marital Transitions: A Family Systems Perspective,” Monographs of the Society for Research in Child Development, 60, $1-14$.

Isaacs, M. (1986). "The Visitation Schedule and Child Adjustment: A Three-Year Study," Unpublished Manuscript.

Johnson, John and Chris Mazingo (2000). "The Economic Consequences of Unilateral Divorce for Children," University of Illinois Office of Research Working Paper

Keith, V. M. and B. Finley (1988). "The Impact of Parental Divorce on Children's Educational Attainment, Marital Timing and Likelihood of Divorce," Journal of Marriage and the Family, 50, 797-809.

Kiernan, Kathleen, and Andrew Cherlin (1999). "Parental Divorce and Partnership Dissolution in Adulthood: Evidence from a British Cohort Study," Population Studies, 53, 39-48.

Kiernan, Kathleen, and John Hobcraft (1997). "Parental Divorce during Childhood: Age at First Intercourse, Partnership and Parenthood," Population Studies, 51, 41-55.

Krein, S. F. and A. H. Beller (1988). "Educational Attainment of Children from Single-Parent Families: Differences by Exposure, Gender and Race," Demography, 25, 221-234.

Matsueda, R. L. and K. Heimer (1987). "Race, Family Structure and Delinquency: A Test of 
Differential Association and Social Control Theories," American Sociological Review, $52,826-40$.

McLanahan, S. and L. Bumpass (1988). "Intergenerational Consequences of Family Disruption," American Journal of Sociology, 94,130-152.

McLanahan, S. and G. Sandefur (1994). "Growing Up with A Single-Parent," Cambridge, MA: Harvard University Press.

McLeod, J. D. (1991). "Childhood Parental Loss and Adult Depression," Journal of Health and Social Behavior, 32, 205-220.

Nordinger, Pia (1998). "The Anti-Divorce Revolution,” The Weekly Standard, March 2.

Peters, H. Elizabeth (1986). "Marriage and Divorce: Informational Constraints and Private Contracting," American Economic Review, 76, 437-54.

Peters, H. Elizabeth (1992). "Marriage and Divorce: Reply," American Economic Review, 82, 686-693.

Reilly, Siobhan and Eirik Evenhouse (1997). "Divorce Laws and Divorce Rates: Evidence from Panel Data," mimeo, Vanderbilt University.

Ross, H. L. and Isabel V. Sawhill (1975). Time of Transition: The Growth of Families Headed by Women. Washington, D.C.: Urban Institute.

Strauss, John and Duncan Thomas (1995). "Human Resources: Empirical Modeling of Household and Family Decisions," In J. Berhrman and T.N. Srinivasan, eds, Handbook of Development Economics, 3A, pp1883-2023.

Weitzman, Lenore (1985). The Divorce Revolution. New York: Free Press.

Wheeler, Michael (1974). No Fault Divorce. Boston: Beach Press.

Wolfers, Justin (2000). "Did Unilateral Divorce Raise Divorce Rates? Reassessing the Evidence," mimeo, Harvard University.

Zill, N., D. R. Morrison and M. J. Coiro (1993). "Long Term Effects Of Parental Divorce on Parent-Child Relationships, Adjustment, and Achievement in Young Adulthood," Journal of Family Psychology, 7, 91-103. 


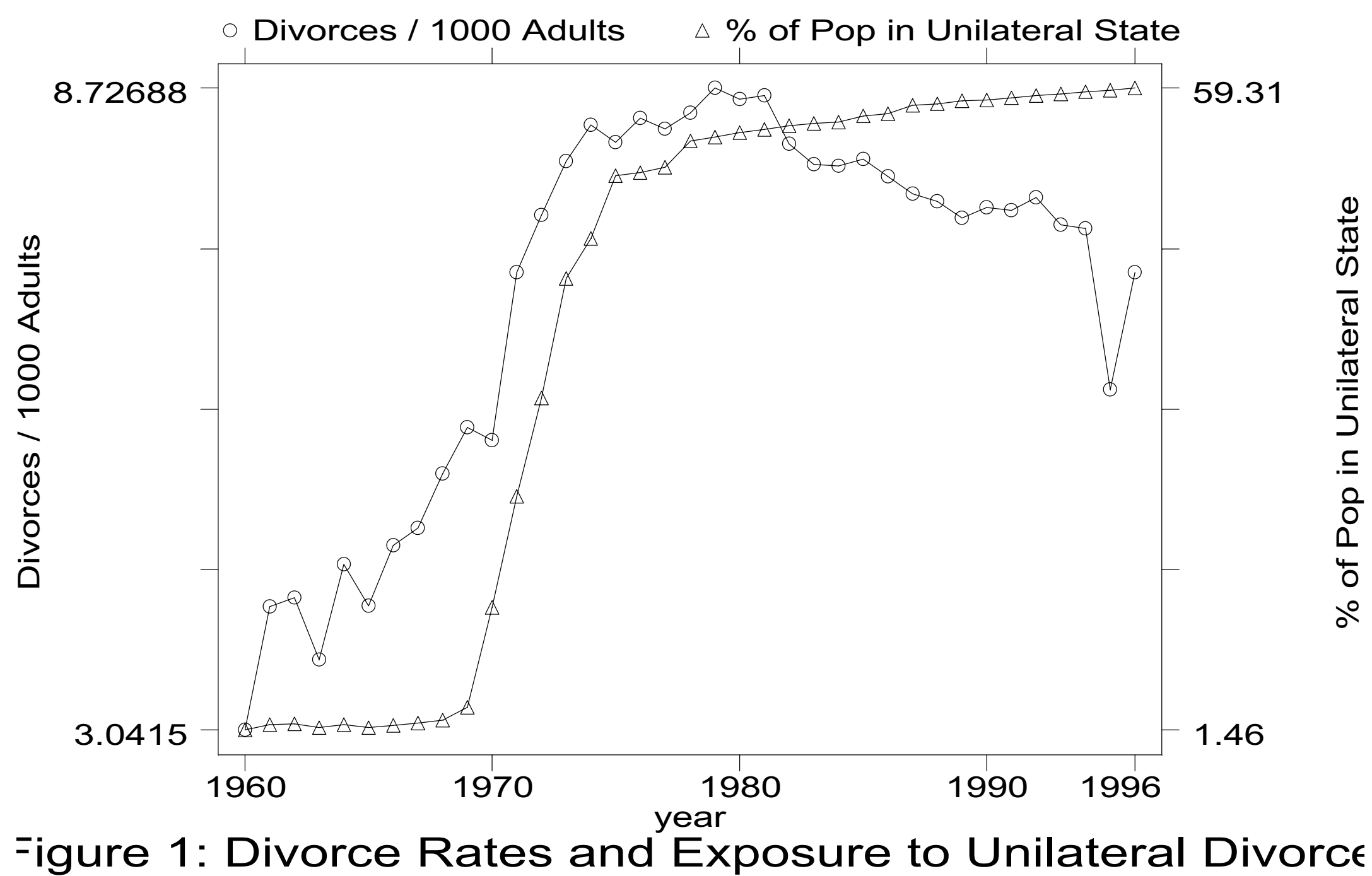




\begin{tabular}{|c|c|c|c|c|c|}
\hline State & $\begin{array}{c}\text { No-Fault } \\
\text { Date }\end{array}$ & $\begin{array}{c}\text { Unilateral } \\
\text { Date }\end{array}$ & State & $\begin{array}{l}\text { No-Fault } \\
\text { Date }\end{array}$ & $\begin{array}{c}\text { Unilateral } \\
\text { Date }\end{array}$ \\
\hline Alabama & 1971 & 1971 & Missouri & 1974 & \\
\hline Alaska & 1935 & 1935 & Montana & 1973 & 1973 \\
\hline Arkansas & 1937 & & Nebraska & 1972 & 1972 \\
\hline Arizona & 1931 & 1973 & Nevada & 1931 & 1967 \\
\hline California & 1970 & 1970 & New Hampshire & 1971 & 1971 \\
\hline Colorado & 1972 & 1972 & New Jersey & 1971 & \\
\hline Connecticut & 1973 & 1973 & New Mexico & 1933 & 1933 \\
\hline $\begin{array}{l}\text { District of } \\
\text { Columbia }\end{array}$ & 1966 & & New York & 1967 & \\
\hline Delaware & 1957 & 1968 & North Carolina & 1910 & \\
\hline Florida & 1971 & 1971 & North Dakota & 1971 & 1971 \\
\hline Georgia & 1973 & 1973 & Ohio & 1974 & \\
\hline Hawaii & 1965 & 1972 & Oklahoma & 1953 & 1953 \\
\hline Idaho & 1945 & 1971 & Oregon & 1971 & 1971 \\
\hline Illinois & 1984 & & Pennsylvania & 1980 & \\
\hline Indiana & 1973 & 1973 & Rhode Island & 1910 & 1975 \\
\hline Iowa & 1970 & 1970 & South Carolina & 1969 & \\
\hline Kansas & 1969 & 1969 & South Dakota & 1985 & 1985 \\
\hline Kentucky & 1962 & 1972 & Tennessee & 1963 & \\
\hline Louisiana & 1916 & & Texas & 1910 & 1970 \\
\hline Maine & 1973 & 1973 & Utah & 1943 & 1987 \\
\hline Maryland & 1969 & & Vermont & 1969 & \\
\hline Massachusetts & 1975 & 1975 & Virginia & 1960 & \\
\hline Michigan & 1972 & 1972 & Washington & 1921 & 1973 \\
\hline Minnesota & 1933 & 1974 & West Virginia & 1969 & \\
\hline Mississippi & 1978 & & & & \\
\hline
\end{tabular}

Note: From author's compilation of previous research and relevant state statutes 


\begin{tabular}{|c|c|c|}
\hline \multicolumn{3}{|c|}{ Table 2: Means } \\
\hline \multicolumn{3}{|c|}{ Children } \\
\hline Mother Divorced & & 0.0664 \\
\hline Mother Separated & & 0.0349 \\
\hline Mother Never Married & & 0.037 \\
\hline Father Divorced & & 0.0099 \\
\hline Father Separated & & 0.00334 \\
\hline Father Never Married & & 0.0036 \\
\hline Income Per Capita & & 8432.73 \\
\hline Number of Obs & & 3876 \\
\hline & emale Adult & Male Adults \\
\hline \multicolumn{3}{|c|}{ Family Structure } \\
\hline Married & 0.717 & 0.726 \\
\hline Divorced & 0.110 & 0.082 \\
\hline Separated & 0.034 & 0.023 \\
\hline Never Married & 0.120 & 0.166 \\
\hline Number of Children & 2.024 & 1.169 \\
\hline \multicolumn{3}{|c|}{ Educational Attainment } \\
\hline Years of Education & 11.683 & 11.933 \\
\hline HS Dropout & 0.189 & 0.195 \\
\hline HS Graduate & 0.365 & 0.308 \\
\hline Some College & 0.216 & 0.216 \\
\hline College Graduate & 0.231 & 0.281 \\
\hline \multicolumn{3}{|c|}{ Living Standards } \\
\hline Income per Capita & 13513.41 & 15159.06 \\
\hline Below Poverty & 0.118 & 0.086 \\
\hline \multicolumn{3}{|c|}{ Labor Supply } \\
\hline Work Last Year & 0.712 & .946 \\
\hline Weeks Worked & 29.758 & 45.040 \\
\hline Earnings & 10682.1 & 26222.66 \\
\hline Number of Observations & 159884 & 159487 \\
\hline
\end{tabular}




\begin{tabular}{|c|c|c|c|c|}
\hline \multicolumn{5}{|c|}{ Adults } \\
\hline & \multicolumn{2}{|c|}{ Females } & \multicolumn{2}{|c|}{ Males } \\
\hline & No Trend & Trend & No Trend & Trend \\
\hline Divorced & $\begin{array}{l}1.277 \\
(.257) \\
{[.116]}\end{array}$ & $\begin{array}{c}1.396 \\
(.43) \\
{[.127]}\end{array}$ & $\begin{array}{c}.948 \\
(.258) \\
{[.116]}\end{array}$ & $\begin{array}{l}.961 \\
(.412) \\
{[.117]}\end{array}$ \\
\hline Separated & $\begin{array}{l}.216 \\
(.148) \\
{[.063]}\end{array}$ & $\begin{array}{l}-.142 \\
(.224) \\
{[.042]}\end{array}$ & $\begin{array}{c}-.057 \\
(.09) \\
{[-.025]}\end{array}$ & $\begin{array}{c}-.097 \\
(.178) \\
{[-.042]}\end{array}$ \\
\hline Never Married & $\begin{array}{c}-.613 \\
(.487) \\
{[-.051]}\end{array}$ & $\begin{array}{c}-.255 \\
(.332) \\
{[-.021]}\end{array}$ & $\begin{array}{c}-.37 \\
(.593) \\
{[-.022]}\end{array}$ & $\begin{array}{c}-.088 \\
(.432) \\
{[-.005]}\end{array}$ \\
\hline Number of Obs & 5304 & 5304 & 5304 & 5304 \\
\hline \multicolumn{5}{|c|}{ Children } \\
\hline & \multicolumn{2}{|c|}{ Living with Mother who is } & \multicolumn{2}{|c|}{ Living with Father who is } \\
\hline Divorced & $\begin{array}{c}.606 \\
(.179) \\
{[.091]}\end{array}$ & $\begin{array}{c}.963 \\
(.281) \\
{[.145]}\end{array}$ & $\begin{array}{l}.192 \\
(.045) \\
{[.194]}\end{array}$ & $\begin{array}{l}.11 \\
(.067) \\
{[.111]}\end{array}$ \\
\hline Separated & $\begin{array}{c}.003 \\
(.204) \\
{[0]}\end{array}$ & $\begin{array}{c}-.251 \\
(.264) \\
{[-.072]}\end{array}$ & $\begin{array}{c}-.016 \\
(.024) \\
{[-.048]}\end{array}$ & $\begin{array}{c}-.001 \\
(.028) \\
{[-.003]}\end{array}$ \\
\hline Never Married & $\begin{array}{c}-1.003 \\
(.225) \\
{[-.271]}\end{array}$ & $\begin{array}{c}-.133 \\
(.201) \\
{[-.036]}\end{array}$ & $\begin{array}{c}-.088 \\
(.033) \\
{[-.244]}\end{array}$ & $\begin{array}{c}-.097 \\
(.043) \\
{[-.269]}\end{array}$ \\
\hline Number of Obs & 3876 & 3876 & 3876 & 3876 \\
\hline
\end{tabular}

Note: Standard errors in parentheses; percentage impacts in square brackets. All coefficients multiplied by 100. Each coefficient is from a separate regression that includes: race; state of residence dummies; age dummies; year dummies; age*year dummy interactions. First panel uses data on adults, examining own marital status, in the first two columns for women, and in the second two columns for men. Second panel uses data on children, examining marital status of the parent with whom they reside; in first two columns dependent variable is for residing with mother who is divorced/separated/never married, and parallel for living with a father in second two columns. First column in each panel excludes state specific linear time trends; second column includes those trends. 


\begin{tabular}{|c|c|c|c|c|}
\hline & \multicolumn{2}{|c|}{ Unilateral as Youth } & \multicolumn{2}{|c|}{ Unilateral as Adult } \\
\hline & No Trend & Trend & No Trend & Trend \\
\hline \multicolumn{5}{|c|}{ Family Structure } \\
\hline Married & $\begin{array}{c}.591 \\
(.246) \\
{[.008]}\end{array}$ & $\begin{array}{c}.664 \\
(.285) \\
{[.009]}\end{array}$ & $\begin{array}{c}-1.263 \\
(.325) \\
{[-.018]}\end{array}$ & $\begin{array}{c}-.734 \\
(.474) \\
{[-.010]}\end{array}$ \\
\hline Divorced & $\begin{array}{c}.058 \\
(.29) \\
{[.005]}\end{array}$ & $\begin{array}{c}.007 \\
(.292) \\
{[.001]}\end{array}$ & $\begin{array}{c}.942 \\
(.141) \\
{[.086]}\end{array}$ & $\begin{array}{l}1.073 \\
(.212) \\
{[.098]}\end{array}$ \\
\hline Separated & $\begin{array}{c}.347 \\
(.091) \\
{[.102]}\end{array}$ & $\begin{array}{c}.326 \\
(.079) \\
{[.096]}\end{array}$ & $\begin{array}{l}.119 \\
(.104) \\
{[.035]}\end{array}$ & $\begin{array}{l}-.166 \\
(.166) \\
{[-.049]}\end{array}$ \\
\hline Never Married & $\begin{array}{c}-1.198 \\
(.469) \\
{[-.1]}\end{array}$ & $\begin{array}{c}-1.222 \\
(.497) \\
{[-.102]}\end{array}$ & $\begin{array}{c}.136 \\
(.298) \\
{[.011]}\end{array}$ & $\begin{array}{c}-.16 \\
(.353) \\
{[-.013]}\end{array}$ \\
\hline $\begin{array}{c}\text { Number of } \\
\text { Children }\end{array}$ & $\begin{array}{c}.011 \\
(.01) \\
{[.005]}\end{array}$ & $\begin{array}{l}.021 \\
(.009) \\
{[.010]}\end{array}$ & $\begin{array}{c}-.054 \\
(.019) \\
{[-.026]}\end{array}$ & $\begin{array}{c}-.017 \\
(.025) \\
{[-.008]}\end{array}$ \\
\hline \multicolumn{5}{|c|}{ Educational Attainment } \\
\hline $\begin{array}{c}\text { Years of } \\
\text { Education }\end{array}$ & $\begin{array}{c}-.076 \\
(.04) \\
{[-.006]}\end{array}$ & $\begin{array}{c}-.065 \\
(.029) \\
{[-.006]}\end{array}$ & $\begin{array}{l}-.132 \\
(.072) \\
{[-.011]}\end{array}$ & $\begin{array}{l}-.025 \\
(.136) \\
{[-.002]}\end{array}$ \\
\hline HS Dropout & $\begin{array}{c}.837 \\
(.51) \\
{[.044]}\end{array}$ & $\begin{array}{l}.622 \\
(.389) \\
{[.033]}\end{array}$ & $\begin{array}{c}2.7 \\
(.86) \\
{[.142]}\end{array}$ & $\begin{array}{c}.195 \\
(1.0) \\
{[.010]}\end{array}$ \\
\hline HS Graduate & $\begin{array}{l}1.05 \\
(.608) \\
{[.029]}\end{array}$ & $\begin{array}{l}1.16 \\
(.422) \\
{[.032]}\end{array}$ & $\begin{array}{c}-4.26 \\
(1.32) \\
{[-.117]}\end{array}$ & $\begin{array}{l}-1.28 \\
(1.85) \\
{[.035]}\end{array}$ \\
\hline Some College & $\begin{array}{c}-.235 \\
(.291) \\
{[-.011]}\end{array}$ & $\begin{array}{c}-.284 \\
(.205) \\
{[-.013]}\end{array}$ & $\begin{array}{c}.932 \\
(.44) \\
{[.043]}\end{array}$ & $\begin{array}{l}2.46 \\
(.933) \\
{[.114]}\end{array}$ \\
\hline $\begin{array}{l}\text { College } \\
\text { Graduate }\end{array}$ & $\begin{array}{c}-1.656 \\
(.533) \\
{[-.072]}\end{array}$ & $\begin{array}{l}-1.497 \\
(.397) \\
{[.065]}\end{array}$ & $\begin{array}{c}.633 \\
(1.054) \\
{[.027]}\end{array}$ & $\begin{array}{c}-1.378 \\
(2.075) \\
{[-.06]}\end{array}$ \\
\hline
\end{tabular}




\begin{tabular}{ccccc}
\hline \multicolumn{5}{c}{ Living Standards } \\
\hline Income Per & -521.35 & -431.63 & 213.45 & 54.21 \\
Capita & $(152.85)$ & $(120.24)$ & $(268.49)$ & $(581.43)$ \\
& {$[-.039]$} & {$[-.032]$} & {$[.016]$} & {$[.004]$} \\
Below Poverty & .026 & .091 & .557 & .343 \\
& $(.234)$ & $(.195)$ & $(.822)$ & $(.747)$ \\
& {$[.002]$} & {$[.008]$} & {$[.047]$} & {$[.029]$} \\
\hline \multirow{2}{*}{ Work Last Year } & -.76 & Labor Supply & & \\
& $(.257)$ & -.478 & 1.284 & 2.197 \\
& {$[-.011]$} & $(.25)$ & $(.502)$ & $(.584)$ \\
Weeks Worked & -.399 & {$[-.007]$} & {$[.018]$} & {$[.031]$} \\
& $(.137)$ & -.32 & .817 & .976 \\
& {$[-.013]$} & $(.127)$ & $(.263)$ & $(.293)$ \\
& & {$[-.010]$} & {$[.027]$} & {$[.033]$} \\
Earnings & -336.35 & -246.28 & 198.77 & 91.01 \\
& $(114.97)$ & $(92.73)$ & $(206.11)$ & $(375.07)$ \\
& {$[-.031]$} & {$[-.023]$} & {$[.019]$} & {$[.009]$} \\
\hline \hline
\end{tabular}

Note: Standard errors in parentheses; percentage impacts in square brackets. Coefficients on dummy variables multiplied by 100 ; coefficients on continuous variables unchanged. First and third columns are from one regression, which excludes state specific time trends; second and fourth columns are from a second regression, which includes linear time trends for both state of residence and state of birth. Each regression also includes: race; state of residence dummies; state of birth dummies; age dummies; year dummies; age*year dummy interactions. 


\begin{tabular}{|c|c|c|c|c|}
\hline & \multicolumn{2}{|c|}{ Unilateral as Youth } & \multicolumn{2}{|c|}{ Unilateral as Adult } \\
\hline & No Trend & Trend & No Trend & Trend \\
\hline \multicolumn{5}{|c|}{ Family Structure } \\
\hline Married & $\begin{array}{c}.555 \\
(.338) \\
{[.008]}\end{array}$ & $\begin{array}{l}.625 \\
(.397) \\
{[.009]}\end{array}$ & $\begin{array}{c}-.926 \\
(.361) \\
{[-.013]}\end{array}$ & $\begin{array}{l}-.693 \\
(.549) \\
{[-.010]}\end{array}$ \\
\hline Divorced & $\begin{array}{c}.027 \\
(.279) \\
{[.003]}\end{array}$ & $\begin{array}{c}-.107 \\
(.272) \\
{[-.013]}\end{array}$ & $\begin{array}{c}.723 \\
(.152) \\
{[.088]}\end{array}$ & $\begin{array}{l}.689 \\
(.208) \\
{[.084]}\end{array}$ \\
\hline Separated & $\begin{array}{l}.248 \\
(.056) \\
{[.108]}\end{array}$ & $\begin{array}{l}.261 \\
(.049) \\
{[.113]}\end{array}$ & $\begin{array}{c}-.116 \\
(.068) \\
{[-.050]}\end{array}$ & $\begin{array}{l}-.065 \\
(.117) \\
{[-.028]}\end{array}$ \\
\hline Never Married & $\begin{array}{c}-.897 \\
(.572) \\
{[-.054]}\end{array}$ & $\begin{array}{c}-.839 \\
(.621) \\
{[-.051]}\end{array}$ & $\begin{array}{c}.315 \\
(.365) \\
{[.019]}\end{array}$ & $\begin{array}{l}.121 \\
(.412) \\
{[.007]}\end{array}$ \\
\hline $\begin{array}{c}\text { Number of } \\
\text { Children }\end{array}$ & $\begin{array}{c}.037 \\
(.013) \\
{[.032]} \\
\end{array}$ & $\begin{array}{c}.046 \\
(.015) \\
{[.040]} \\
\end{array}$ & $\begin{array}{c}-.074 \\
(.016) \\
{[-.063]}\end{array}$ & $\begin{array}{c}-.054 \\
(.022) \\
{[-.046]} \\
\end{array}$ \\
\hline \multicolumn{5}{|c|}{ Educational Attainment } \\
\hline $\begin{array}{l}\text { Years of } \\
\text { Education }\end{array}$ & $\begin{array}{c}-.079 \\
(.054) \\
{[-.007]}\end{array}$ & $\begin{array}{c}-.072 \\
(.039) \\
{[-.006]}\end{array}$ & $\begin{array}{c}-.076 \\
(.096) \\
{[-.006]}\end{array}$ & $\begin{array}{l}.041 \\
(.192) \\
{[.003]}\end{array}$ \\
\hline HS Dropout & $\begin{array}{l}1.05 \\
(.488) \\
{[.054]}\end{array}$ & $\begin{array}{c}.889 \\
(.367) \\
{[.046]}\end{array}$ & $\begin{array}{l}1.584 \\
(.856) \\
{[.081]}\end{array}$ & $\begin{array}{c}-.272 \\
(1.219) \\
{[-.014]}\end{array}$ \\
\hline HS Graduate & $\begin{array}{c}.633 \\
(.51) \\
{[.021]}\end{array}$ & $\begin{array}{c}.781 \\
(.329) \\
{[.025]}\end{array}$ & $\begin{array}{l}-3.627 \\
(1.125) \\
{[-.118]}\end{array}$ & $\begin{array}{l}-1.329 \\
(1.771) \\
{[-.043]}\end{array}$ \\
\hline Some College & $\begin{array}{c}-.364 \\
(.204) \\
{[-.017]}\end{array}$ & $\begin{array}{c}-.335 \\
(.165) \\
{[-.016]}\end{array}$ & $\begin{array}{c}.575 \\
(.368) \\
{[.027]}\end{array}$ & $\begin{array}{l}2.484 \\
(.679) \\
{[.115]}\end{array}$ \\
\hline $\begin{array}{l}\text { College } \\
\text { Graduate }\end{array}$ & $\begin{array}{c}-1.32 \\
(.642) \\
{[-.047]}\end{array}$ & $\begin{array}{c}-1.335 \\
(.493) \\
{[-.048]}\end{array}$ & $\begin{array}{c}1.468 \\
(1.252) \\
{[.052]}\end{array}$ & $\begin{array}{c}-.883 \\
(2.702) \\
{[-.031]}\end{array}$ \\
\hline
\end{tabular}




\begin{tabular}{|c|c|c|c|c|}
\hline \multicolumn{5}{|c|}{ Living Standards } \\
\hline $\begin{array}{c}\text { Income Per } \\
\text { Capita }\end{array}$ & $\begin{array}{c}-431.96 \\
(157.73) \\
{[-.028]}\end{array}$ & $\begin{array}{c}-266.72 \\
(137.14) \\
{[-.018]}\end{array}$ & $\begin{array}{c}237.45 \\
(295.54) \\
{[.016]}\end{array}$ & $\begin{array}{c}255.44 \\
(604) \\
{[.017]}\end{array}$ \\
\hline Below Poverty & $\begin{array}{c}-.08 \\
(.199) \\
{[-.009]}\end{array}$ & $\begin{array}{c}.057 \\
(.149) \\
{[.007]}\end{array}$ & $\begin{array}{c}.398 \\
(.798) \\
{[.046]}\end{array}$ & $\begin{array}{c}.502 \\
(.604) \\
{[.058]}\end{array}$ \\
\hline \multicolumn{5}{|c|}{ Labor Supply } \\
\hline Work Last Year & $\begin{array}{c}.083 \\
(.127) \\
{[.001]}\end{array}$ & $\begin{array}{l}.161 \\
(.111) \\
{[.019]}\end{array}$ & $\begin{array}{c}.301 \\
(.165) \\
{[.035]}\end{array}$ & $\begin{array}{c}.259 \\
(.32) \\
{[.030]}\end{array}$ \\
\hline Weeks Worked & $\begin{array}{c}-.017 \\
(.102) \\
{[0]}\end{array}$ & $\begin{array}{l}.103 \\
(.097) \\
{[.002]}\end{array}$ & $\begin{array}{c}.235 \\
(.132) \\
{[.005]}\end{array}$ & $\begin{array}{c}.281 \\
(.210) \\
{[.006]}\end{array}$ \\
\hline Earnings & $\begin{array}{c}93.65 \\
(251.53) \\
{[.004]}\end{array}$ & $\begin{array}{c}418.8 \\
(285.78) \\
{[.016]}\end{array}$ & $\begin{array}{c}-54.36 \\
(446.30) \\
{[-.002]}\end{array}$ & $\begin{array}{c}309.73 \\
(1014.33) \\
{[.012]}\end{array}$ \\
\hline
\end{tabular}

Note: Standard errors in parentheses; percentage impacts in square brackets. Coefficients on dummy variables multiplied by 100 ; coefficients on continuous variables unchanged. First and third columns are from one regression, which excludes state specific time trends; second and fourth columns are from a second regression, which includes linear time trends for both state of residence and state of birth. Each regression also includes: race; state of residence dummies; state of birth dummies; age dummies; year dummies; age*year dummy interactions. 


\begin{tabular}{|c|c|c|c|c|c|c|}
\hline & \multicolumn{6}{|c|}{ Adults } \\
\hline & \multicolumn{3}{|c|}{ Females } & \multicolumn{3}{|c|}{ Males } \\
\hline & 1-4 Years & 5-8 Years & $9+$ Years & 1-4 Years & 5-8 Years & $9+$ Years \\
\hline Divorced & $\begin{array}{c}.568 \\
(.416) \\
{[.052]}\end{array}$ & $\begin{array}{l}1.677 \\
(.446) \\
{[.152]}\end{array}$ & $\begin{array}{c}2.08 \\
(.789) \\
{[.189]}\end{array}$ & $\begin{array}{c}.521 \\
(.38) \\
{[.064]}\end{array}$ & $\begin{array}{l}1.183 \\
(.418) \\
{[.144]}\end{array}$ & $\begin{array}{l}1.724 \\
(.726) \\
{[.210]}\end{array}$ \\
\hline Separated & $\begin{array}{c}-.19 \\
(.237) \\
{[-.056]}\end{array}$ & $\begin{array}{c}-.161 \\
(.247) \\
{[-.047]}\end{array}$ & $\begin{array}{c}-.33 \\
(.315) \\
{[-.097]}\end{array}$ & $\begin{array}{c}-.179 \\
(.175) \\
{[-.078]}\end{array}$ & $\begin{array}{c}-.107 \\
(.198) \\
{[-.047]}\end{array}$ & $\begin{array}{c}-.271 \\
(.267) \\
{[-.118]}\end{array}$ \\
\hline $\begin{array}{c}\text { Never } \\
\text { Married }\end{array}$ & $\begin{array}{c}.163 \\
(.369) \\
{[.014]}\end{array}$ & $\begin{array}{c}-.245 \\
(.36) \\
{[-.020]}\end{array}$ & $\begin{array}{c}.382 \\
(.599) \\
{[.032]}\end{array}$ & $\begin{array}{c}-.02 \\
(.367) \\
{[-.001]}\end{array}$ & $\begin{array}{c}.01 \\
(.466) \\
{[.001]}\end{array}$ & $\begin{array}{l}.609 \\
(.642) \\
{[.037]}\end{array}$ \\
\hline \multicolumn{7}{|c|}{ Children } \\
\hline & \multicolumn{3}{|c|}{ Living with Mother who is } & \multicolumn{3}{|c|}{ Living with Father who is } \\
\hline Divorced & $\begin{array}{c}.736 \\
(.17) \\
{[.111]}\end{array}$ & $\begin{array}{l}1.177 \\
(.207) \\
{[.177]}\end{array}$ & $\begin{array}{l}1.088 \\
(.313) \\
{[.164]}\end{array}$ & $\begin{array}{c}.005 \\
(.029) \\
{[.005]}\end{array}$ & $\begin{array}{c}.172 \\
(.035) \\
{[.174]}\end{array}$ & $\begin{array}{c}.263 \\
(.057) \\
{[.266]}\end{array}$ \\
\hline Separated & $\begin{array}{c}-.128 \\
(.183) \\
{[-.037]}\end{array}$ & $\begin{array}{c}-.598 \\
(.245) \\
{[-.171]}\end{array}$ & $\begin{array}{c}-.715 \\
(.248) \\
{[-.205]}\end{array}$ & $\begin{array}{c}.016 \\
(.018) \\
{[.048]}\end{array}$ & $\begin{array}{c}-.021 \\
(.024) \\
{[-.063]}\end{array}$ & $\begin{array}{c}-.045 \\
(.025) \\
{[-.135]}\end{array}$ \\
\hline $\begin{array}{c}\text { Never } \\
\text { Married }\end{array}$ & $\begin{array}{c}-.196 \\
(.154) \\
{[-.053]}\end{array}$ & $\begin{array}{c}.282 \\
(.215) \\
{[.076]}\end{array}$ & $\begin{array}{c}.772 \\
(.268) \\
{[.209]}\end{array}$ & $\begin{array}{c}-.106 \\
(.04) \\
{[-.294]}\end{array}$ & $\begin{array}{c}-.152 \\
(.07) \\
{[-.422]}\end{array}$ & $\begin{array}{c}-.208 \\
(.092) \\
{[-.578]}\end{array}$ \\
\hline
\end{tabular}

Note: Standard errors in parentheses; percentage impacts in square brackets. All coefficients multiplied by 100. Each set of coefficients from a separate regression that includes: race; state of residence dummies; age dummies; year dummies; age*year dummy interactions; and statespecific linear time trends. First panel uses data on adults, examining own marital status, in the first three columns for women, and in the second three columns for men. Second panel uses data on children, examining marital status of the parent with whom they reside; in first three columns dependent variable is for residing with mother who is divorced/separated/never married, and parallel for living with a father in second three columns. Each set of three columns is from same regression that replaces UNILAT dummy with dummies for exposure for 1-4, 5-8 and 9 or more years. 


\begin{tabular}{|c|c|c|c|c|c|c|}
\hline & & Females & & & Males & \\
\hline & 1-4 Years & 5-8 Years & $9+$ Years & 1-4 Years & 5-8 Years & $9+$ Years \\
\hline \multicolumn{7}{|c|}{ Family Structure } \\
\hline Married & $\begin{array}{c}.525 \\
(.295) \\
{[.007]}\end{array}$ & $\begin{array}{c}.428 \\
(.327) \\
{[.006]}\end{array}$ & $\begin{array}{l}1.171 \\
(.519 \\
{[.016]}\end{array}$ & $\begin{array}{c}.481 \\
(.357) \\
{[.007]}\end{array}$ & $\begin{array}{c}.264 \\
(.481) \\
{[.004]}\end{array}$ & $\begin{array}{c}1.219 \\
(.81) \\
{[.017]}\end{array}$ \\
\hline Divorced & $\begin{array}{c}.031 \\
(.236) \\
{[.003]}\end{array}$ & $\begin{array}{c}.051 \\
(.319) \\
{[.005]}\end{array}$ & $\begin{array}{c}.046 \\
(.53) \\
{[.004]}\end{array}$ & $\begin{array}{c}-.041 \\
(.239) \\
{[-.005]}\end{array}$ & $\begin{array}{c}-.032 \\
(.278) \\
{[-.004]}\end{array}$ & $\begin{array}{c}-.189 \\
(.492) \\
{[-.023]}\end{array}$ \\
\hline Separated & $\begin{array}{c}.206 \\
(.068) \\
{[.061]}\end{array}$ & $\begin{array}{c}.35 \\
(.093) \\
{[.103]}\end{array}$ & $\begin{array}{c}.622 \\
(.15) \\
{[.183]}\end{array}$ & $\begin{array}{l}.204 \\
(.046) \\
{[.089]}\end{array}$ & $\begin{array}{c}.25 \\
(.062) \\
{[.109]}\end{array}$ & $\begin{array}{l}.404 \\
(.117) \\
{[.176]}\end{array}$ \\
\hline $\begin{array}{l}\text { Never } \\
\text { Married }\end{array}$ & $\begin{array}{c}-.93 \\
(.416) \\
{[-.078]}\end{array}$ & $\begin{array}{c}-1.092 \\
(.536) \\
{[-.091]}\end{array}$ & $\begin{array}{c}-2.158 \\
(1.014) \\
{[-.18]}\end{array}$ & $\begin{array}{c}-.699 \\
(.55) \\
{[-.042]}\end{array}$ & $\begin{array}{c}-.541 \\
(.659) \\
{[-.033]}\end{array}$ & $\begin{array}{c}-1.51 \\
(1.255) \\
{[-.091]}\end{array}$ \\
\hline $\begin{array}{l}\text { Number of } \\
\text { Children }\end{array}$ & $\begin{array}{c}.008 \\
(.008) \\
{[.004]}\end{array}$ & $\begin{array}{l}.021 \\
(.012) \\
{[.010]}\end{array}$ & $\begin{array}{c}.056 \\
(.116) \\
{[.028]}\end{array}$ & $\begin{array}{l}.034 \\
(.013) \\
{[.029]}\end{array}$ & $\begin{array}{c}.042 \\
(.02) \\
{[.036]}\end{array}$ & $\begin{array}{c}.08 \\
(.023) \\
{[.068]}\end{array}$ \\
\hline \multicolumn{7}{|c|}{ Educational Attainment } \\
\hline $\begin{array}{l}\text { Years of } \\
\text { Education }\end{array}$ & $\begin{array}{c}-.052 \\
(.027) \\
{[-.005]}\end{array}$ & $\begin{array}{c}-.062 \\
(.032) \\
{[-.005]}\end{array}$ & $\begin{array}{c}-.088 \\
(.042) \\
{[-.008]}\end{array}$ & $\begin{array}{c}-.058 \\
(.037) \\
{[-.005]}\end{array}$ & $\begin{array}{c}-.064 \\
(.041) \\
{[-.005]}\end{array}$ & $\begin{array}{c}-.092 \\
(.059) \\
{[-.008]}\end{array}$ \\
\hline $\begin{array}{c}\text { HS } \\
\text { Dropout }\end{array}$ & $\begin{array}{c}.504 \\
(.349) \\
{[.027]}\end{array}$ & $\begin{array}{c}.549 \\
(.428) \\
{[.029]}\end{array}$ & $\begin{array}{c}.837 \\
(.643) \\
{[.044]}\end{array}$ & $\begin{array}{c}.629 \\
(.326) \\
{[.032]}\end{array}$ & $\begin{array}{l}.852 \\
(.397) \\
{[.044]}\end{array}$ & $\begin{array}{l}1.435 \\
(.686) \\
{[.074]}\end{array}$ \\
\hline $\begin{array}{c}\text { HS } \\
\text { Graduate }\end{array}$ & $\begin{array}{c}.826 \\
(.385) \\
{[.023]}\end{array}$ & $\begin{array}{c}1.27 \\
(.462) \\
{[.0345]}\end{array}$ & $\begin{array}{l}1.815 \\
(.617) \\
{[.05]}\end{array}$ & $\begin{array}{c}.643 \\
(.316) \\
{[.021]}\end{array}$ & $\begin{array}{c}.72 \\
(.438) \\
{[.023]}\end{array}$ & $\begin{array}{c}.928 \\
(.49) \\
{[.030]}\end{array}$ \\
\hline $\begin{array}{c}\text { Some } \\
\text { College }\end{array}$ & $\begin{array}{c}-.086 \\
(.182) \\
{[-.004]}\end{array}$ & $\begin{array}{c}-.469 \\
(.271) \\
{[-.022]}\end{array}$ & $\begin{array}{c}-.395 \\
(.38) \\
{[-.018]}\end{array}$ & $\begin{array}{c}-.089 \\
(.169) \\
{[-.004]}\end{array}$ & $\begin{array}{c}-.561 \\
(.24) \\
{[-.026]}\end{array}$ & $\begin{array}{c}-.44 \\
(.272) \\
{[-.020]}\end{array}$ \\
\hline $\begin{array}{l}\text { College } \\
\text { Graduate }\end{array}$ & $\begin{array}{c}-1.244 \\
(.336) \\
{[-.054]}\end{array}$ & $\begin{array}{c}-1.35 \\
(.463) \\
{[-.058]}\end{array}$ & $\begin{array}{c}-2.257 \\
(.631) \\
{[-.098]}\end{array}$ & $\begin{array}{c}-1.183 \\
(.429) \\
{[-.042]}\end{array}$ & $\begin{array}{c}-1.011 \\
(.584) \\
{[-.036]}\end{array}$ & $\begin{array}{c}-1.922 \\
(.857) \\
{[-.068]}\end{array}$ \\
\hline
\end{tabular}




\begin{tabular}{ccccccc}
\hline \multicolumn{7}{c}{ Living Standards } \\
\hline Income Per & -261.93 & -512.04 & -800.44 & -141.23 & -254.24 & -610.26 \\
Capita & $(108.83)$ & $(147.76)$ & $(168.93)$ & $(127.24)$ & $(169.57)$ & $(201.49)$ \\
& {$[-.019]$} & {$[-.038]$} & {$[-.059]$} & {$[-.009]$} & {$[-.017]$} & {$[-.040]$} \\
Below & -.016 & -.006 & .405 & -.074 & .085 & .317 \\
Poverty & $(.212)$ & $(.251)$ & $(.331)$ & $(.147)$ & $(.218)$ & $(.254)$ \\
& {$[-.001]$} & {$[-.001]$} & {$[.034]$} & {$[-.009]$} & {$[.01]$} & {$[.037]$} \\
\hline & & & Labor Supply & & & \\
\hline Work Last &.- .303 & -.255 & -.902 & .127 & .231 & .102 \\
Year & $(.265)$ & $(.303)$ & $(.335)$ & $(.106)$ & $(.14)$ & $(.173)$ \\
& {$[-.004]$} & {$[-.004]$} & {$[-.013]$} & {$[.001]$} & {$[.002]$} & {$[.001]$} \\
Weeks & -.176 & -.155 & -.679 & .114 & .092 & .038 \\
Worked & $(.139)$ & $(.164)$ & $(.173)$ & $(.094)$ & $(.1)$ & $(.173)$ \\
& {$[-.006]$} & {$[-.005]$} & {$[-.023]$} & {$[.003]$} & {$[.002]$} & {$[.001]$} \\
Earnings & -105.41 & -243.36 & -624.72 & 310.17 & 368.27 & 592.12 \\
& $(95.42)$ & $(118.47)$ & $(134.90)$ & $(216.24)$ & $(289.11)$ & $(494.99)$ \\
& {$[-.010]$} & {$[-.023]$} & {$[.058]$} & {$[.012]$} & {$[.014]$} & {$[.023]$} \\
\hline \hline
\end{tabular}

Note: Standard errors in parentheses; percentage impacts in square brackets. All coefficients multiplied by 100. Each set of coefficients from a separate regression that includes: race; state of residence dummies; age dummies; year dummies; age*year dummy interactions; and statespecific linear time trends. First set of columns presents results for women, second set for men. Each set of three columns is from same regression that replaces UNILAT dummy with dummies for exposure for 1-4, 5-8 and 9 or more years. 


\begin{tabular}{|c|c|c|c|c|}
\hline & \multicolumn{2}{|c|}{ Unilateral as Youth } & \multicolumn{2}{|c|}{ Unilateral as Adult } \\
\hline & Unilateral & $\begin{array}{c}\text { Unilateral * } \\
\text { (Age - 24) }\end{array}$ & Unilateral & $\begin{array}{c}\text { Unilateral * } \\
\text { (Age - 24) }\end{array}$ \\
\hline \multicolumn{5}{|c|}{ Females } \\
\hline Married & $\begin{array}{l}1.496 \\
(.438) \\
{[.021]}\end{array}$ & $\begin{array}{c}-.133 \\
(.04) \\
{[-.002]}\end{array}$ & $\begin{array}{c}-.782 \\
(.591) \\
{[-.011]}\end{array}$ & $\begin{array}{c}-.005 \\
(.025) \\
{[0]}\end{array}$ \\
\hline Divorced & $\begin{array}{c}.406 \\
. .31) \\
{[.037]}\end{array}$ & $\begin{array}{c}-.037 \\
(.02) \\
{[-.003]}\end{array}$ & $\begin{array}{l}.788 \\
(.246) \\
{[.072]}\end{array}$ & $\begin{array}{c}.026 \\
(.016) \\
{[.002]}\end{array}$ \\
\hline Separated & $\begin{array}{c}.427 \\
(.091) \\
{[.126]}\end{array}$ & $\begin{array}{c}-.026 \\
(.008) \\
{[-.008]}\end{array}$ & $\begin{array}{c}-.073 \\
(.186) \\
{[-.021]}\end{array}$ & $\begin{array}{c}-.011 \\
(.006) \\
{[-.003]}\end{array}$ \\
\hline Never Married & $\begin{array}{l}-2.26 \\
(.664) \\
{[-.188]}\end{array}$ & $\begin{array}{l}.184 \\
(.052) \\
{[.015]}\end{array}$ & $\begin{array}{c}-.28 \\
(.492) \\
{[-.023]}\end{array}$ & $\begin{array}{c}.025 \\
(.032) \\
{[.002]}\end{array}$ \\
\hline \multicolumn{5}{|c|}{ Males } \\
\hline Married & $\begin{array}{l}1.745 \\
(.592) \\
{[.024]}\end{array}$ & $\begin{array}{c}-.17 \\
(.051) \\
{[-.002]}\end{array}$ & $\begin{array}{c}-.851 \\
(.718) \\
{[-.012]}\end{array}$ & $\begin{array}{c}.004 \\
(.032) \\
{[0]}\end{array}$ \\
\hline Divorced & $\begin{array}{c}.239 \\
(.309) \\
{[.029]}\end{array}$ & $\begin{array}{c}-.019 \\
(.026) \\
{[-.002]}\end{array}$ & $\begin{array}{l}.306 \\
(.202) \\
{[.037]}\end{array}$ & $\begin{array}{c}.037 \\
(.013) \\
{[.005]}\end{array}$ \\
\hline Separated & $\begin{array}{c}.279 \\
(.074) \\
{[.121]}\end{array}$ & $\begin{array}{l}-.014 \\
(.007) \\
{[-.006]}\end{array}$ & $\begin{array}{c}.043 \\
(.124) \\
{[.019]}\end{array}$ & $\begin{array}{l}-.012 \\
(.004) \\
{[-.005]}\end{array}$ \\
\hline Never Married & $\begin{array}{c}-2.256 \\
(.819) \\
{[-.136]}\end{array}$ & $\begin{array}{l}.199 \\
(.061) \\
{[.012]}\end{array}$ & $\begin{array}{c}.479 \\
(.646) \\
{[.029]}\end{array}$ & $\begin{array}{c}-.022 \\
(.041) \\
{[-.001]}\end{array}$ \\
\hline
\end{tabular}

Note: Standard errors in parentheses; percentage impacts in square brackets. All coefficients multiplied by 100 . Each set of coefficients from a separate regression that includes: race; state of residence dummies; age dummies; year dummies; age*year dummy interactions; and statespecific linear time trends. Each row reports coefficients from one regression that includes current exposure, youth exposure, and interactions of each exposure dummy with (current age 24). First panel is for females; second for males. 